\title{
Training to address vaccine hesitancy in first-year students
}

\author{
La Vonne Downey iD, Cara Brock \\ Roosevelt University, Chicago, Illinois, United States
}

\section{Keywords}

Covid-19 vaccine

Motivational interviewing

Pharmacy education

Vaccine hesitancy

\author{
Correspondence \\ La Vonne Downey \\ Roosevelt University \\ Health sciences administration \\ Chicago \\ United States \\ Idowney@roosevelt.edu
}

\begin{abstract}
Aim: This study's aim was to determine if an additional educational component on pharmacy students can increase their knowledge and skill level to address vaccine hesitancy and/or refusal related to a future Covid 19 vaccine. Methods: First-year pharmacy students were given additional education beyond what they received in their Accreditation Council for Pharmaceutical Education (ACPE) module, on motivational interviewing (MI). They were given a pre-and postsurvey assessing their knowledge and confidence in addressing vaccine hesitancy and the application of MI. This study was approved by the Institutional Review Board (IRB). Results: This study showed that additional motivational interviewing education had a significant impact on the student's knowledge, self-assessment of skills in talking to patients, and understanding how the skills impacted patients regarding vaccines both general and Covid-19 vaccines. Conclusion: The study's findings indicate that additional training that focuses on motivational methods to engage patients is needed for students to be able to address vaccine hesitancy, especially when a new vaccine using different science is on the market.
\end{abstract}

\section{Introduction}

Vaccines do not save lives; vaccination saves lives. This is a fundamental idea during the Covid-19 pandemic as a vaccine is seen as the solution by many health officials and policymakers. The arrival of a vaccine does not necessarily mean people get to a vaccination rate of $70 \%$ or more, which is needed for herd immunity according to the Centre for Diseases Control (CDC) (Santibanez et al., 2016). A recent Gallup poll has shown that a significant number of Americans are hesitant to get a Covid-19 vaccine. Only 58 to $60 \%$ of those surveyed stated they would get a covid vaccine once available. Those numbers remain even if the vaccine was Food and Drug Administration (FDA) approved and given for free.

Even more concerning is who would or would not get the vaccine; polls such as Pew and Gallop found a racial divide with $75 \%$ of whites and only $54 \%$ of Blacks stating they would get the vaccine. These numbers are concerning in that potentially a significant amount of those at risk in workplaces and schools might be resistant to getting a vaccine. This indicates that policymakers in government, healthcare, industry, and education will need to anticipate a way to encourage a more comprehensive level of Covid-19 vaccinations to reduce the risk of the pandemic continuing. One such way to increase the use of the Covid-19 vaccine is to use pharmacists. Pharmacists are already seen as advocates and educators by the patients they serve. Moreover, for those patients with chronic conditions, the pharmacist often sees them monthly. This provides them with more touchpoint to connect and educate the patient on their vaccine-related needs. At present, most pharmacies offer a range of vaccines to which the Covid-19 could be added. Pharmacies are also more convenient for patients as more than $90 \%$ of Americans live within five miles of a pharmacy, they have longer hours, often including holidays and weekends, and there is no need for an appointment (ACPE, 2016). Thus, to educate and vaccinate a wide range of Americans with the Covid-19 vaccine, pharmacists and community pharmacies must focus on improving vaccination access to the potential Covid vaccine. 
Pharmacist training supports this concept with the 2017 Accreditation Committee Pharmacy Education (ACPE) stating that pharmacists should be patient advocates with an understanding of patient beliefs while promoting population-based health (ACPE, 2016). Pharmacists do receive as part of their training ways to inform and advocate for vaccines as part of patient care (Jarrett et al., 2015; ACPE, 2016). The potential addition of a Covid-19 vaccine, with what is known about the numbers and types of patients who might present as Covid-19 vaccine-hesitant, indicates a need for additional training (Horne et al., 2015). Thus, a pharmacist must receive training on how to communicate and address the causes of vaccine hesitation.

However, just relaying the facts is not shown to be impactful or effective (Diekema, 2012; Sadaf et al., 2013; Jarrett et al., 2015; Horne et al., 2015). In order to promote vaccines, a multi-prong approach is needed. A conversation that is focused on vaccines is more patient-focused. This approach needs to show specific components as listed below: 1) A genuine interest in the patient/child; 2) Acknowledging the risks and benefits of vaccines; 4) Identify the patients' concerns with a response to those specific concerns; and 5) Using emotions and social storytelling with an emphasis on personal stories to relate about the impact of not vaccinating when talking about what the illness may have on the patients (Diekema, 2012; Sadaf et al., 2013; Horne et al., 2015; Jarrett et al., 2015; WHO, 2016).

The newer approach is beyond the skill in the immunisation training given to the majority of a pharmacist. Instead, the standard training focuses on clinical information about vaccines and the best practice in administering them (ACPE, 2016). The American Pharmacy Association (APhA) programme is formal training, and there is a section on motivational interviewing and how to talk to hesitant patients or patient representatives, but it is not extensive, and since the programme is not updated in real-time, there is a need to include covid specific concerns. The standard way to train pharmacy students before clinical placement would be done using a pre-and post-assessment of skills. The assessment would include using a standardised patient in a clinical setting with a trained clinician that determines the student's competency levels. The training of pharmacists in the field is usually done with online continuing medical education (CME) that ends with a true/false and or question-based quiz to determine knowledge gained.

However, the issue was how to provide this additional motivational interview (MI) training and updates of new information in response to a new highly contagious virus that resulted in a global pandemic. The vaccine to be given was developed within a short period, using a new vaccine technology. Information about the threat of the virus and the development of the vaccines was ongoing and changing in real-time. Due to the pandemic, the pharmacy students were not allowed on campus, with all education and assessment done online before going to clinical sites where they would potentially be giving the Covid-19 vaccine to their patients. Thus, the purpose of this study was to determine if an additional educational component on first-year pharmacy students can increase their knowledge and skill level to address vaccine hesitancy and or refusal related to a future Covid-19 vaccine.

\section{Methods}

The study's site was an accelerated pharmacy school with 55 first-year students in 2021. First-year students had completed the American pharmacist Immunisation training during the first part of their first year. First-year students had an amount of patient experience before taking part in this additional training. A vaccine hesitancy training related to the potential Covid-19 vaccination was added to part of their first year's training. This was done to ensure that these students had the skills and confidence to address general and Covid-19 vaccine literacy and patient hesitancy prior to their onsite clinics. Before the educational intervention on using Motivational Interviewing (MI) communication, the students are to complete a survey assessing their knowledge of standard vaccination controversy, including Covid-19 related issues, communication abilities, and roles and responsibilities. The survey measures the four common myths about vaccines as identified by the World Health Organisation (WHO) (WHO, 2016), as shown in Table I.

The questions include the following: 1) Vaccines overwhelming the person/child's immune system, in the case of flu and covid vaccination; 2) Why do we have to get the vaccine every year; 3 ) Vaccines causing the illness they are supposed to prevent; 4) Vaccines containing harmful additives such as Thermasol, and 5) Vaccines causing side effects (in the case of a potential change in the patient's DNA due to covid vaccine). The students then rated taped interactions with simulated patient interactions between a pharmacist and vaccine-hesitant patients (as shown in Table II). 
Table I: Confidence in knowledge and skills survey given pre-and-post educational intervention

\begin{tabular}{|c|}
\hline $\begin{array}{l}\text { Confidence in your knowledge of the following vaccine } \\
\text { controversies: }\end{array}$ \\
\hline Use of thimerosal (mercury) as a preservative. \\
\hline Use of DNA to make Covid vaccine \\
\hline Use of fetal or animal cells to make vaccines \\
\hline Vaccines causing autism, and or other illnesses \\
\hline Vaccines causing the illness they are designed to prevent. \\
\hline Herd effect offers protection for those who are not immunised. \\
\hline $\begin{array}{l}\text { Too many vaccines overwhelming the child's/patients immune } \\
\text { system. }\end{array}$ \\
\hline $\begin{array}{l}\text { Confidence in your ability to speak to a parent or patient } \\
\text { about: }\end{array}$ \\
\hline Vaccines causing autism. \\
\hline Vaccines causing the illness they are designed to prevent. \\
\hline $\begin{array}{l}\text { How the herd effect offers protection to those who are not } \\
\text { immunised. }\end{array}$ \\
\hline $\begin{array}{l}\text { Too many vaccines overwhelming a child's/patients immune } \\
\text { system. }\end{array}$ \\
\hline Level of agreement with : \\
\hline $\begin{array}{l}\text { It is my job to convince patients of the benefits of getting } \\
\text { vaccinated. }\end{array}$ \\
\hline Pharmacists are well-suited to impact vaccination rates. \\
\hline $\begin{array}{l}\text { Vaccines should be mandatory for all except those with } \\
\text { documented contraindications }\end{array}$ \\
\hline $\begin{array}{l}\text { Parents should not be allowed to exempt their children from } \\
\text { vaccines }\end{array}$ \\
\hline $\begin{array}{l}\text { Only a physician should be able to exempt a patient from } \\
\text { receiving a vaccine }\end{array}$ \\
\hline
\end{tabular}

Two of the videos were ineffective examples of using motivational learning techniques, and two were effective examples of motivational intervention focusing on Covid-19 vaccines (Murphy, 2015; Vyasd80, 2016a; Vyasd80; 2016b). The grading was done using a scale of poor $=1$, satisfactory $=2$, effective $=3$. These were based on standardised scenarios covering the four areas identified by the WHO (WHO, 2016). Students evaluated it if the pharmacist asked questions, provided counselling, mediated the conflict and maintained patient-provider relationships despite disagreement. Students would then receive online training using videos and in person, done by a Pharm. D. graduate on how to communicate with patients who exhibit vaccination hesitancy. Students were given in February 2021 up-to-date information on the covid - 19 vaccination science and process. The student then rated different taped interactions between a pharmacist and a patient who exhibits vaccine hesitancy. Once the students had watched the different scenarios and graded them, they again were
Table II: Student assessment tool for responding to scenarios

\author{
Finds any underlying hesitancy or misinformation that can be \\ corrected. \\ Validates the patient's concerns. \\ Provides patients with information to dispel the myth. \\ Provides the patient with some disease facts to back their \\ "education." \\ Discusses benefits of vaccines. \\ Acknowledges possible risks of vaccines. \\ Respects the patient's authority and develops the ability to have \\ shared decision making \\ Solicits and welcomes questions. \\ Uses lay language (appropriate language for patient's \\ understanding). \\ Engaged in consultation. \\ Maintains eye contact \\ Expresses empathy for patient. \\ Resolves patient's concerns. \\ Did the student show regard for the patient?
}

Was the student successful at establishing a positive clientpatient relationship?

Would this student have been successful in getting the patient to change his/her mind?

Source: (Vyas et al., 2018)

given the post-survey assessing their knowledge and scenarios of their communication abilities. The survey gave an indication and a measure of if the training increased the knowledge of the students and helped build speaking skills for vaccine-hesitant patients. (Vyas et al., 2018). In order to test their additional and improved skills in motivational interviewing related to Covid-19 vaccine hesitancy and literacy, the students took part in an in-class simulation; using a script, they took turns being the pharmacist and the vaccinehesitant patient. This was done by randomly assigning students to break out rooms using zoom, where they were given scripts. The simulation allowed them to apply their new skill set. The post-intervention survey, rating of videos, and in-class simulation measured if the training increased and built skills in speaking to Covid19 vaccine-hesitant and low literacy patients. This study was approved by Institutional Review Board (IRB). The flow chart of how and when the study was administered can be found in Figure 1 . 


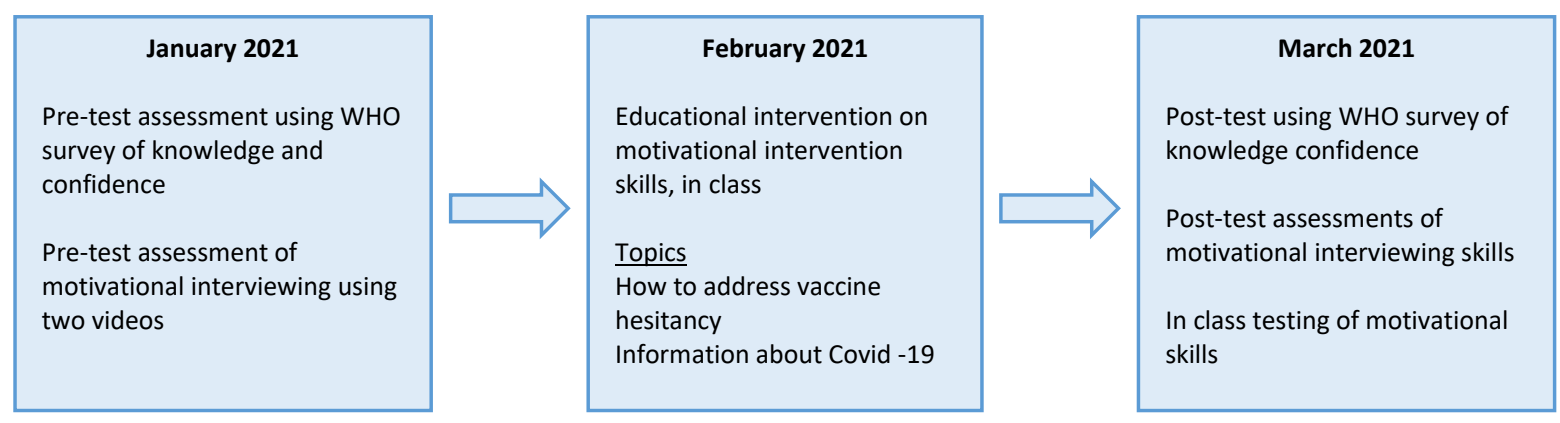

Figure 1: Flowchart of how and when the study was administered

Using SPSS version 25, a $t$-test comparison was used to determine if there was a significant difference at the 0.05 or less level between pre-and post-test survey responses and skill assessment. Additional descriptive statistics were used to report students self-reported responses to the in-class role-playing module.

\section{Results}

A total of 51 first-year students took part in the pre-and post-test surveys, video and in-person assessment of skills. The responses to the pre-test survey of selfassessment of skills illustrated that the students were confident in their skills to talk to patients and were less confident in their knowledge about typical and covid vaccines. The first group of students illustrated a dichotomy in that they felt confident to speak to patients despite 25 to $50 \%$ of them not being sure of their knowledge on topics related to the vaccine, including covid vaccine safety, materials, and vaccine hesitancy. The most significant lacked confidence or was unsure of how vaccines were made and the materials. This finding was seen as $50 \%$ were not confident/neutral in their knowledge about the use or non-use of thimerosal, this was part of the questions in the WHO survey noted in methods that $43 \%$ used DNA and MrDNA in covid vaccines, $38 \%$ agreed that too many vaccines (more than one) overwhelm a person's immune system, $24 \%$ believed that vaccines could cause autism, and $22 \%$ agreed that herd effect protects those that are not immunised.

A lack of confidence, despite successfully completing their American Pharmacist training in their knowledge, impacted their self-assessment of talking to patients about these issues. The lower confidence can be seen with the $22-34 \%$ that were not confident in their ability to talk about vaccine hesitancy-related issues. The largest at $34 \%$, were not confident/neutral in their ability to talk to patients about how too many vaccines could overwhelm a patient's immune system, a third $(30 \%)$ were not confident/neutral in their ability to speak to patients about vaccines causing autism, $20 \%$ of those vaccines caused the illness they were meant to prevent. Students at $95 \%$ felt that convincing patients about the benefits of vaccines, including the covid vaccines, was part of their job. They also, at $96 \%$, saw those pharmacists were well suited to impact covid vaccine rates. Seventy-seven per cent strongly felt that vaccines should be mandatory, $61 \%$ that exemptions should be limited, and $58 \%$ that only a physician should exempt patients from vaccines.

Students could determine a difference between the two taped interactions before the educational intervention on communicating with vaccine-hesitant patients. The first taped interaction did not use the motivational intervention technique. The video's impact on addressing a vaccine-hesitant patient was deemed moderately effective by $60 \%$ of students; $40 \%$ found that the pharmacist effectively validated the patients' concerns. They thought it was less effective $(62 \%)$ in addressing the patients' concerns by responding with relevant information, $67 \%$ stated it was effective in explaining the risks of the vaccine, and $51 \%$ stated this led to the patients continuing to have a mistrust of vaccines. It was difficult for the students to discern (only 25\%) if the patient and pharmacist could establish a positive patient and provider relationship regarding vaccines.

The second taped interactions did use the motivational intervention, and students said the use of MI was able to alleviate and address the patient's vaccine hesitancy. Using the technique, the respondents thought that at $81 \%$, it addressed and validated the patient's concerns and explained the role of immunity (77\%) and benefits (73\%). The use of the technique appeared to respect the patient's authority (84\%) through engagement with the pharmacist $(90 \%)$, showed a higher level of concern for the patients $(84 \%)$, which shows a high level of concern for the patient's well-being, thus being very effective (88\%) in establishing a positive pharmacist and patients relationship about vaccines.

There was a significant difference post the motivational intervention and the covid vaccine education module. 
The intervention had a significant impact on both the participants' ability to talk to patients about vaccine issues and increase their confidence in their knowledge on these subjects. Thus, the intervention impacted not just the student's knowledge but also their confidence to speak about vaccines in general and covid vaccines in specific. There was a significant increase for the following areas: 1) Confidence about preservatives $(p=0.01) ; 2)$ Use of DNA to make covid vaccines $(p=0.01) ; 3)$ Use of fetal or animal cells to make vaccines $(p=0.01)$; 4) Caused autism $(p=0.01) ; 5)$ Cause illness meant to prevent $(p=0.02)$; 6) Overwhelm persons system $(p=0.04)$. Table III shows the results of the preand post-test comparison. According to the table, the students did not gain significant confidence in the role of the pharmacist as vaccine advocates. These results were in part due to the high level of confidence the respondent showed during the pre-test. The viewing of the video of a pharmacist and a hesitant vaccine patient did show a change in how negatively and positively they rated the interactions. Students rated the video that displayed a non-motivational approach more harshly. The most significant shift in all the questions was from those rating the video as moderately effective in the pre-test to not-effective or slightly effective after the post motivational education analysis.

There were some significant differences between the positive videos from the pre-to-post test. The posted video specifically focused on an interaction between a pharmacist and a hesitant vaccine patient around the Covid-19 vaccination. The changes were in the following areas: 1) Validating patients concerns $(p=0.01)$; 2) Acknowledges the possible risks of the vaccine $(p=0.01)$; 3$)$ Respects the patient's authority and develops the ability to share decisions $(p=0.02) ; 4)$ Appears engaged in the consultation $(p=0.01)$, and 5$)$ Solicits and welcomes questions $(p=0.02)$. The most significant shift in all these questions was slightly and moderately effective to very and highly effective. After the students were exposed to motivational intervention education and were to apply it to their learning in the role-play interactions, they all stated it was difficult. When they were in the pharmacist's role, their first response was to overwhelm the patient with facts and data and to interrupt the patient when they said incorrect information. As patients, they stated that it was great to be heard and engaged with even if they did not feel the information would have changed the patient's mind. In the discussion, the students saw how different the motivational approach was and its impact on building and maintaining the pharmacist-patient relationship.

They did find the motivational interviewing education and application helpful. This was evident when the students had to apply what they had learned using a script, with one person being the patient and the other the pharmacist. They then switched to opposite roles again using a script. Despite the educational intervention, $90 \%$ of students found it hard not to "data dump" on the vaccine-hesitant patient. They all stated that they were able to apply the new skill set during the simulation. Over half said they better understood how being listened to their vaccine concerns when they were the patient.

Table III: Pre-test to post-test comparison

\begin{tabular}{|c|c|c|c|}
\hline Question & Pre-test & Post-test & $\%$ change \\
\hline $\begin{array}{l}\text { Rate your confidence in your knowledge of the } \\
\text { following vaccine controversies: - Use of } \\
\text { thimerosal (mercury) as a preservative }\end{array}$ & $\begin{array}{l}\text { Not confident- } 26.3 \% \\
\text { Neutral- } 24.6 \% \\
\text { Confident- } 49.1 \%\end{array}$ & $\begin{array}{l}\text { Not confident- } 4 \% \\
\text { Neutral- } 4 \% \\
\text { Confident- } 92 \%\end{array}$ & $\begin{array}{l}\text { Not confident- }-22.3 \% \\
\text { Neutral- }-20.6 \% \\
\text { Confident- } 42.9 \%\end{array}$ \\
\hline $\begin{array}{l}\text { Rate your confidence in your knowledge of the } \\
\text { following vaccine controversies: - Use of DNA to } \\
\text { make Covid vaccine }\end{array}$ & $\begin{array}{l}\text { Not confident- } 26.3 \% \\
\text { Neutral- } 17.5 \% \\
\text { Confident- } 56.1 \%\end{array}$ & $\begin{array}{l}\text { Not confident- } 2 \% \\
\text { Neutral- } 8 \% \\
\text { Confident- } 90 \%\end{array}$ & $\begin{array}{l}\text { Not confident- }-24.3 \% \\
\text { Neutral- }-9.5 \% \\
\text { Confident- }+33.9 \% \\
p=0.01\end{array}$ \\
\hline $\begin{array}{l}\text { Rate your confidence in your knowledge of the } \\
\text { following vaccine controversies: - Use of fetal or } \\
\text { animal cells to make vaccine }\end{array}$ & $\begin{array}{l}\text { Not confident- } 24.5 \% \\
\text { Neutral- } 22.8 \% \\
\text { Confident- } 52.6 \%\end{array}$ & $\begin{array}{l}\text { Not confident- } 6.0 \% \\
\text { Neutral- } 10.0 \% \\
\text { Confident- } 84 \%\end{array}$ & $\begin{array}{l}\text { Not confident- }-18.5 \% \\
\text { Neutral- }-12.8 \% \\
\text { Confident- }+31.4 \% \\
p=0.01\end{array}$ \\
\hline $\begin{array}{l}\text { Rate your confidence in your knowledge of the } \\
\text { following vaccine controversies: - Vaccines } \\
\text { causing autism or other illnesses }\end{array}$ & $\begin{array}{l}\text { Not confident- } 17.5 \% \\
\text { Neutral- } 7 \% \\
\text { Confident- } 75.5 \%\end{array}$ & $\begin{array}{l}\text { Not confident- } 0 \% \\
\text { Neutral- } 8.2 \% \\
\text { Confident- } 91.8 \%\end{array}$ & $\begin{array}{l}\text { Not confident- }-17.5 \% \\
\text { Neutral- }+1.2 \% \\
\text { Confident- }+16.3 \% \\
p=0.01\end{array}$ \\
\hline $\begin{array}{l}\text { Rate your confidence in your knowledge of the } \\
\text { following vaccine controversies: - Vaccines } \\
\text { causing the illness they are meant to prevent }\end{array}$ & $\begin{array}{l}\text { Not confident- } 12.5 \% \\
\text { Neutral- } 12.5 \% \\
\text { Confident- } 75 \%\end{array}$ & $\begin{array}{l}\text { Not confident- } 2 \% \\
\text { Neutral- } 0 \% \\
\text { Confident- } 98 \%\end{array}$ & $\begin{array}{l}\text { Not confident- }-10.5 \% \\
\text { Neutral- }-12.5 \% \\
\text { Confident- }+23 \%\end{array}$ \\
\hline
\end{tabular}




\begin{tabular}{|c|c|c|c|}
\hline Question & Pre-test & Post-test & $\%$ change \\
\hline $\begin{array}{l}\text { Rate your confidence in your knowledge of the } \\
\text { following vaccine controversies: - Herd effect } \\
\text { offering protection for those who are not } \\
\text { immunised }\end{array}$ & $\begin{array}{l}\text { Not confident- } 8.8 \% \\
\text { Neutral- } 14 \% \\
\text { Confident- } 77.2 \%\end{array}$ & $\begin{array}{l}\text { Not confident- } 2 \% \\
\text { Neutral- } 4 \% \\
\text { Confident- } 94 \%\end{array}$ & $\begin{array}{l}\text { Not confident- }-6.8 \% \\
\text { Neutral- }-10 \% \\
\text { Confident- } 16.8 \%\end{array}$ \\
\hline $\begin{array}{l}\text { Rate your confidence in your knowledge of the } \\
\text { following vaccine controversies: - Too many } \\
\text { vaccines overwhelming the child or person's } \\
\text { immune system }\end{array}$ & $\begin{array}{l}\text { Not confident- } 8.8 \% \\
\text { Neutral- } 29.8 \% \\
\text { Confident- } 61.4 \%\end{array}$ & $\begin{array}{l}\text { Not confident- } 4 \% \\
\text { Neutral- } 4 \% \\
\text { Confident- } 92 \%\end{array}$ & $\begin{array}{l}\text { Not confident- }-11.8 \% \\
\text { Neutral- }-25.8 \% \\
\text { Confident- }+30.6 \%\end{array}$ \\
\hline $\begin{array}{l}\text { Rate your confidence in your ability to speak to a } \\
\text { parent or patient about the following vaccine } \\
\text { related topics: - Vaccines causing autism }\end{array}$ & $\begin{array}{l}\text { Not confident- } 14.2 \% \\
\text { Neutral- } 16.1 \% \\
\text { Confident- } 69.7 \%\end{array}$ & $\begin{array}{l}\text { Not confident- } 2 \% \\
\text { Neutral- } 12 \% \\
\text { Confident- } 86 \%\end{array}$ & $\begin{array}{l}\text { Not confident- }-12.2 \% \\
\text { Neutral- }-4.1 \% \\
\text { Confident- }+16.3 \% \\
p=0.01\end{array}$ \\
\hline $\begin{array}{l}\text { Rate your confidence in your ability to speak to a } \\
\text { parent or patient about the following vaccine } \\
\text { related topics: - Vaccines causing the illness they } \\
\text { are meant to prevent }\end{array}$ & $\begin{array}{l}\text { Not confident- } 10.7 \% \\
\text { Neutral- } 10.7 \% \\
\text { Confident- } 78.6 \%\end{array}$ & $\begin{array}{l}\text { Not confident- } 2 \% \\
\text { Neutral- } 0 \% \\
\text { Confident- } 98 \%\end{array}$ & $\begin{array}{l}\text { Not confident- }-8.7 \% \\
\text { Neutral- }-10.7 \% \\
\text { Confident- }+19.4 \% \\
p=0.02\end{array}$ \\
\hline $\begin{array}{l}\text { Rate your confidence in your ability to speak to a } \\
\text { parent or patient about the following vaccine } \\
\text { related topics: - How the herd effect offers } \\
\text { protection to those who are not immunised }\end{array}$ & $\begin{array}{l}\text { Not confident- } 5.4 \% \\
\text { Neutral- } 10.7 \% \\
\text { Confident- } 84 \%\end{array}$ & $\begin{array}{l}\text { Not confident- } 2 \% \\
\text { Neutral- } 4 \% \\
\text { Confident- } 94 \%\end{array}$ & $\begin{array}{l}\text { Not confident- }-3.4 \% \\
\text { Neutral- }-6.7 \% \\
\text { Confident- }+10 \%\end{array}$ \\
\hline $\begin{array}{l}\text { Rate your confidence in your ability to speak to a } \\
\text { parent or patient about the following vaccine } \\
\text { related topics: - Too many vaccines } \\
\text { overwhelming a child's or patients immune } \\
\text { system }\end{array}$ & $\begin{array}{l}\text { Not confident- } 14.3 \% \\
\text { Neutral- } 19.6 \% \\
\text { Confident- } 66.1 \%\end{array}$ & $\begin{array}{l}\text { Not confident- } 2 \% \\
\text { Neutral- } 10 \% \\
\text { Confident- } 88 \%\end{array}$ & $\begin{array}{l}\text { Not confident- }-12.3 \% \\
\text { Neutral- }-9.6 \% \\
\text { Confident- }+21.9 \% \\
p=0.04\end{array}$ \\
\hline $\begin{array}{l}\text { Rate your confidence in your ability to speak to a } \\
\text { parent or patient about the following vaccine } \\
\text { related topics: - Vaccines causing the illness they } \\
\text { are meant to prevent }\end{array}$ & $\begin{array}{l}\text { Not confident- } 14.2 \% \\
\text { Neutral- } 10.7 \% \\
\text { Confident- } 75 \%\end{array}$ & $\begin{array}{l}\text { Not confident- } 0 \% \\
\text { Neutral- } 6 \% \\
\text { Confident- } 92 \%\end{array}$ & $\begin{array}{l}\text { Not confident- }-14.2 \% \\
\text { Neutral- }-4.7 \% \\
\text { Confident- }+17 \% \\
p=0.01\end{array}$ \\
\hline $\begin{array}{l}\text { Rate your level of agreement with the following } \\
\text { statements: - It is my job to convince patients of } \\
\text { the benefits of getting vaccinated }\end{array}$ & $\begin{array}{l}\text { Not confident- } 1.8 \% \\
\text { Neutral- } 3.5 \% \\
\text { Confident- } 94.8 \%\end{array}$ & $\begin{array}{l}\text { Not confident- } 0 \% \\
\text { Neutral- } 4 \% \\
\text { Confident- } 96 \%\end{array}$ & $\begin{array}{l}\text { Not confident- }-1.8 \% \\
\text { Neutral- } 0.5 \% \\
\text { Confident- } 1.2 \%\end{array}$ \\
\hline $\begin{array}{l}\text { Rate your level of agreement with the following } \\
\text { statements: - Pharmacists are well-suited to } \\
\text { impact vaccination rates }\end{array}$ & $\begin{array}{l}\text { Not confident- } 0 \% \\
\text { Neutral- } 3.5 \\
\text { Confident- } 96.5 \%\end{array}$ & $\begin{array}{l}\text { Not confident- } 2 \% \\
\text { Neutral- } 0 \% \\
\text { Confident- } 98 \%\end{array}$ & $\begin{array}{l}\text { Not confident- }+2 \% \\
\text { Neutral- }-3.5 \% \\
\text { Confident- }+1.5 \%\end{array}$ \\
\hline $\begin{array}{l}\text { Rate your level of agreement with the following } \\
\text { statements: - Vaccines should be mandatory for } \\
\text { all except those with documented } \\
\text { contraindications }\end{array}$ & $\begin{array}{l}\text { Not confident- } 10.5 \% \\
\text { Neutral- } 15.8 \% \\
\text { Confident- } 73.7 \%\end{array}$ & $\begin{array}{l}\text { Not confident- } 6 \% \\
\text { Neutral- } 26 \% \\
\text { Confident- } 68 \%\end{array}$ & $\begin{array}{l}\text { Not confident- }-4.5 \% \\
\text { Neutral- }+10.2 \% \\
\text { Confident- }-5.7 \%\end{array}$ \\
\hline $\begin{array}{l}\text { Rate your level of agreement with the following } \\
\text { statements: - Patients should not be allowed to } \\
\text { exempt their children from vaccines }\end{array}$ & $\begin{array}{l}\text { Not confident- } 15.8 \% \\
\text { Neutral- } 22.8 \% \\
\text { Confident- } 61.5 \%\end{array}$ & $\begin{array}{l}\text { Not confident- } 10 \% \\
\text { Neutral- } 34 \% \\
\text { Confident- } 56 \%\end{array}$ & $\begin{array}{l}\text { Not confident- }-5.8 \% \\
\text { Neutral- }+11.2 \% \\
\text { Confident- }-5.5 \%\end{array}$ \\
\hline $\begin{array}{l}\text { Rate your level of agreement with the following } \\
\text { statements: - Only a physician should be able to } \\
\text { exempt a patient from receiving a vaccine }\end{array}$ & $\begin{array}{l}\text { Not confident- } 12.3 \% \\
\text { Neutral- } 29.8 \% \\
\text { Confident- } 57.9 \%\end{array}$ & $\begin{array}{l}\text { Not confident- } 20 \% \\
\text { Neutral- } 22 \% \\
\text { Confident- } 58 \%\end{array}$ & $\begin{array}{l}\text { Not confident- } 7.7 \% \\
\text { Neutral- }-7.8 \% \\
\text { Confident- }+0.1 \%\end{array}$ \\
\hline
\end{tabular}

\section{Discussion}

This study showed that additional motivational interviewing education had a significant impact on the student's knowledge, self-assessment of skills in talking to patients, and understanding how the skills impacted patients regarding vaccines in general and Covid-19 vaccines in specific. This finding indicates that additional training in motivational interventions needs to occur above and beyond the APhA training the students had received before their education. The 
application and evaluation of motivational interviewing with the videos and the role-playing enhanced and enabled a more nuanced understanding of how to use it and what it can accomplish when engaging with hesitant vaccine patients, as several studies have shown (ACPE, 2016). Engaging in the role-playing and viewing the videos, students had a more concrete understanding that relaying the facts was not impactful or effective (Horne et al., 2015; WHO, 2016). They had a more nuanced understanding that promoting vaccines, especially a new one such as Covid-19 required a newer approach. The post-educational intervention and role-play focus more on a conversation about patient-focused vaccines. The students were able to both use and rate as a more practical approach that is acknowledging the risks and benefits of vaccines, identify the patients concerns with a response to those specific concerns with an emphasis on personal stories such as why the student would get the vaccine when talking about gathe illness may have on the patient (Diekema, 2012; Sadaf et al., 2013; Horne et al., 2015; Jarrett et al., 2015; WHO, 2016). The ability to see and then be involved with role-playing appeared in this study to build upon and give more depth to the skills learned during their previous education in their APhA training is helpful to address general and Covid-19 hesitancy.

\section{Limitation}

This study was done with first-year students at one educational location. Although many of these students have previous experience working with patients before their pharmacy education, it may have impacted the learning and skills they acquired during this study. Students with less previous experience might have gained even more from the motivational training. The study took place during the Covid-19 pandemic when two new vaccines were brought to market. The impact of new vaccines might have heightened the student's engagement with the new learning of motivational engagement and their knowledge growth. If this study had been done before the pandemic, students might have been less engaged in acquiring the skill and possibly less likely to use it.

\section{Conclusion}

Additional motivational learning positively impacted students' knowledge, skills, and understanding of engaging with vaccine-hesitant patients. Applying what the students have learned was beneficial to better assist them in addressing a new Covid-19 vaccine. These findings might indicate that additional APhA training that focuses on motivational methods to engage patients is needed for students and possibly for pharmacy providers, especially when a new vaccine using different science is on the market. Thus, there is a need to add to the education already given to pharmacists to give them the skills to engage those patients with vaccine hesitancy around Covid-19. The training will ensure that the vaccine provider can ensure overall vaccination rates for the populations they serve.

\section{References}

Accreditation Council for Pharmacy Education. (2016). Standards and key elements for the professional programme in Pharmacy leading to the doctor of pharmacy degree. Standards. https://www.acpeaccredit.org/pdf/Standards2016FINAL.pdf

Diekema, D.S. (2012). Improving childhood vaccination rates. The New England Journal of Medicine. 366(5), 391393

Gallup Poll. (2020). One in three Americans would not get Covid-19 Vaccine (online). Available at: https://news.gallup.com/poll/317018/one-three-americansnot-covid-vaccine.aspx

Horne, Z., Powell, D., Hummel, J.E., Holyoak, K.J. (2015). Countering antivaccination attitudes. Proceedings of the National Academy of Sciences of the United States of America. 112(33), 10321-10324. https://doi.org/10.1073/pnas.1504019112

Jarrett, C., Wilson, R., O'Leary, M., Eckersberger, E., Larson, H.J. (2015). SAGE Working group on vaccine hesitancy: Strategies for addressing vaccine hesitancy - a systematic review. Vaccine. 33(34), 4180-4190. https://doi.org/10.1016/j.vaccine.2015.04.040

Murphy L. (2015). MI - Vaccine Advice(Cut) - Ineffective Pharmacist. Available at: https://www.youtube.com/watch?v=p9zAFdnqdjo\&ab_cha nnel=LauraMurphy

Sadaf, A., Richards, J.L., Glanz, J., Salmon, D.A., Omer, S.B. (2013). A systematic review of interventions for reducing parenteral vaccine refusal and vaccine hesitancy. Vaccine. 31(40), 4293-4304.

https://doi.org/10.1016/j.vaccine.2013.07.013

Santibanez, T.A., Kahn, K.E., Zhai, Y., O'Halloran, A., Liu, L., Bridges, C.B., Lu, P., Greby, S.M., Williams, W.W., Singleton, J.A. (2016). Flu vaccination coverage. Available at: www.cdc.gov/flu/pdf/fluvaxview/2015-16/nfid-coverage2015-16-final.pdf

Vyas, D., Galal, S.M., Rogan, E.L., Boyce, E.G. (2018). Training students to address vaccine hesitancy and/or refusal. American Journal of Pharmacy Education. 82(8), 6338. https://doi.org/10.5688/ajpe6338

Vyasd80. (2016a). Example of an inappropriate vaccine education session. Available at: 
https://www.youtube.com/watch?v=fOA8TiL1or0\& $t=293 s \&$ ab_channel=vyasd 80

Vyasd80. (2016b). Dispelling vaccine myths. Available at: https://www.youtube.com/watch?v=Xwtzoh_nd1c\&ab_cha nnel=vyasd 80

World Health Organisation. (2016). Vaccination and Immunisation (online). Available at:

https://www.who.int/health-topics/vaccines-andimmunization\#tab=tab_1 